\title{
Investigation the effects of 6 weeks pilates exercises on biomotorical variables and self-esteem scores of young women
}

\author{
Ozhan BAVLI, Ozlem KOYBASI \\ School of Physical Education and Sport, Çanakkale Onsekiz Mart University, Çanakkale, Turkey. \\ Address Correspondence to Ö. Bavl, e-mail; ozhanbavli@hotmail.com
}

\begin{abstract}
Purpose of this study was the investigate the effects of six weeks mat based pilates exercise on biomotirical variables and self esteem of young women. Totally 22 women (mean age; 20.1 \pm 2.2 year) participated in to the study voluntary. Participants divided into the two groups (pilates:10, control: 12) randomly. Pilates group did pilates exercise for six weeks. Control group did nothing. Pretests and post tests measurements of body height, body weight, flexibility, balance, abdominal strength and self esteem performed. SPSS used for analysis. Analysis showed that there were statistical findings $(\mathrm{p}<0.05)$ on pretest and post test measurements of pilates group of flexibility, abdominal strength, and self esteem variables $(\mathrm{p}<0.05)$. When comparison the measurement pretest and post test differences of two groups, there was a statistical differences about flexibility, balance, and abdominal strength. According to findings it is possible to say that six weeks of pilates exercise is the proper exercise type for young girls. Also it can be advice that for positive effecting to self esteem pilates works were preferable exercise methods for young women.
\end{abstract}

Keywords: Pilates, exercise, women, bio motor, self esteem.

\section{INTRODUCTION}

Because of the technological development inactivity became the one of the major reason of health problems. Day by day people spent most of their time by sitting. Experts advised and encouraged to people doing daily physical activity to reduce the risk of health problems. There are many types of exercise which help physical condition fit but people may don't prefer participate regularly most of them because of the including long duration or heavy loading of exercise. Researchers also noticed that while regular exercise can improve physical fitness (16), the more intense the exercise the more injury will occur (15). Especially young girls may more affected by that situation because of the strength and endurance performance if compared with the adults. Enjoyable and proper exercise types needs to advice to young girls. Thanks to Joseph Humbertus Pilates (1880-1967) who described pilates exercise method, nowadays over million participants prefer doing that exercise worldwide (7).
Pilates is an exercise protocol to enhance muscular strength, flexibility, and endurance while it also improved bodily concentration and balance (12). The exercises can be carried in two different ways namely Pilates mat work and the use of Pilates apparatus. (27). Pilates exercises did positive effects on flexibility, balance, muscular strength and posture reported by researcher $(18,21,31)$. Researchers also advised it to adults because of its' benefits $(24,35)$. Effects of pilates workouts on young girls are still unclear. There are many studies in literature that investigated the effects of regular exercises on psychological parameters but there weren't any findings about the effects of pilates workouts on self-esteem. Especially effects of short term pilates workouts on young girls needs to investigation. Because of this problem, this study decided to perform.

\section{MATERIALS \& METHOD}

Participants; Totally twenty two female university students average ages $20.10 \pm 2.27$ years were participated in to the study voluntary. Inclusion criteria were being between the ages of 18- 
25 years, without any health problems and never had a pilates courses before. Exclusion criteria were lack of full participation in training activities, history of previous muscle injury for a period of 6 weeks. All participants signed an informed consent form before the beginning of the study.

Procedure; Study designed a single blind, randomized control trail. Students are invited to selection after the announcement for the study, Participants who had inclusion criteria divided in two groups that Pilates group $(\mathrm{n}=10)$ and Control group $(\mathrm{n}=12)$ randomly.

Pilates group performed two sessions per week of mat based pilates exercises (one hour per session). The exercise intensity was followed as described by Gorji et al. 2014 and Pilates courses were led by an IPF certificated mat Pilates instructor. Control group did not participate in any activity during study. Control group was instructed to don't participate new exercise program. Abdominal strength, flexibility, static balance and self-esteem variables were evaluated at baseline and after six weeks of training.

Measurements; Abdominal strength evaluated by using one minute sit-up test (11). After one trial, number of sit-up performance recorded. Flexibility evaluated by using standard sit-and-reach test after three trial best distance was recorded (2) Static balance was evaluated using the single-legged Flamingo balance test. One minute of stance was performed and the number of falls were counted and used as a measure of postural balance (10).

Self-esteem evaluated by using Coopersmith Self-esteem Inventory -short form which was developed by Stanley Coopersmith (1967) and adapted in to Turkish by Tufan \& Turan (1987) (39). The questionnaires consisted of 25 sentences with the options'like me' (1 point) or 'not like $\mathrm{me}^{\prime}(0$ point). Answers multiplied with 4 and self-esteem score was made. Self-esteem levels are rated as having a high (70-100), middle (30-69) or low (0-30) point on the Scale (39). In this study, Cronbach's was .72.

Statistical analysis; All data are expressed as mean \pm and Standard Deviations (SD) and are analyzed using SPSS statistical program to calculate the means and SD of the values collected. The differences between two groups are examined by an independent $\mathrm{t}$-test. Using paired $\mathrm{t}$-tests, the groups are compared before and after the exercises. For $\mathrm{P}<0.05$ is considered statistically significant in the interpretation of our results.

\section{RESULTS}

The physical characteristics of both groups are presented in Table 1. According to table totally 22 participant attempted in to the study and their average ages, body height and body weight were $20.10 \pm 2.27$ years, $159.63 \pm 6.97 \mathrm{~cm}, 56.63 \pm 8.13 \mathrm{~kg}$ found respectively.

Table 1. Demographic characteristics of participants (Mean \pm SD).

\begin{tabular}{lccc}
\hline Groups & Age (year) & Height $(\mathrm{cm})$ & Weight $(\mathrm{kg})$ \\
\hline Pilates (n:10) & $18.4 \pm 0.52$ & $158.43 \pm 7.11$ & $55.21 \pm 6.77$ \\
Control (n:12) & $21.5 \pm 2.20$ & $160.63 \pm 6,99$ & $57.8 \pm 9.24$ \\
Total (n:22) & $20.10 \pm 2.27$ & $159.63 \pm 6.97$ & $56.63 \pm 8.13$ \\
\hline
\end{tabular}

Table 3. Pre-test and Post-test differences of groups (Mean \pm SD).

\begin{tabular}{lcc}
\hline \multirow{2}{*}{ Variables } & \multicolumn{2}{c}{ Groups } \\
\cline { 2 - 3 } & Pilates & Control \\
\hline Flexibility $(\mathrm{cm})$ & $5.7 \pm 6.9^{*}$ & $0.6 \pm 1.4$ \\
Static balance (trial) & $-0.1 \pm 0.3$ & $-0.3 \pm 0.6$ \\
Abdominal strength (repetition) & $15.7 \pm 5.6^{*}$ & $2.1 \pm 3.1$ \\
Self esteem & $9.2 \pm 11.7$ & $0.1 \pm 16.2$ \\
BMI $\left(\mathrm{kg} / \mathrm{m}^{2}\right)$ & $-0.1 \pm 0.4$ & $0.1 \pm 0.5$ \\
\hline * Significant differences at $\mathrm{p}<0.05$ level between two groups
\end{tabular}

* Significant differences at $\mathrm{p}<0.05$ level between two groups

\begin{tabular}{lcccc} 
Table 2. Pre-test and post test measurements of groups (Mean \pm SD). \\
\cline { 2 - 5 } Variables & \multicolumn{2}{c}{ Pilates } & \multicolumn{2}{c}{ Control } \\
\cline { 2 - 5 } & Pre-test & Post-test & Pre-test & Post-test \\
\hline Flexibility $(\mathrm{cm})$ & $21.6 \pm 7,2$ & $27.3 \pm 8.6^{*}$ & $21.4 \pm 5.5$ & $22.1 \pm 6.1$ \\
Static balance (trial) & $1.1 \pm 0.32$ & $1 \pm 0.1$ & $1.4 \pm 0.6$ & $1.09 \pm 0.2$ \\
Abdominal strength (repetition) & $18.9 \pm 7.1$ & $34.6 \pm 8.2^{*}$ & $28.1 \pm 12.9$ & $30.2 \pm 14.1^{*}$ \\
Self esteem & $76.4 \pm 10.5$ & $85.6 \pm 6.1^{*}$ & $72.3 \pm 15.5$ & $72.3 \pm 16.1$ \\
BMI $\left(\mathrm{kg} / \mathrm{m}^{2}\right)$ & $22.1 \pm 2.8$ & $22.1 \pm 2.5$ & $22.3 \pm 2.2$ & $22.3 \pm 2.2$ \\
\hline
\end{tabular}

* Significant differences at $\mathrm{p}<0.05$ level between pre-test and post-test 
Findings about mean values of pre-test and post-test measurements showed at Table 2. After six weeks of trainings flexibility performance of pilates group was significantly increased from $21.6 \pm 7.2 \mathrm{~cm}$ to $27.3 \pm 8.6 \mathrm{~cm}$. Paired $\mathrm{t}$-test analysis proved that this change was statistically different $(t=-2.588 ; p=0.02)$. However analysis showed that flexibility performance of control group was no significant. Abdominal strength of pilates group was significantly increased from $18.9 \pm 7.1$ repetition to $34.6 \pm 8.2$ repetition. Paired t-test analysis proved that this change was statistically different $(\mathrm{t}=-8.837 ; \mathrm{p}=$ 0.01). Beside abdominal strength of control group was significantly increased from $28.1 \pm 12$.9 repetition to $30.2 \pm 14.1$ repetition. This change was statistically different $(\mathrm{t}=-2.359 ; \mathrm{p}=0.03)$. Another important finding was about the self-esteem scores of pilates group. It was significantly increased from $76.4 \pm 10.5$ to 85.6 \pm 6.1 . Analysis also proved that this change was statistically different $(t=-2.469 ; p=0.03)$.

Pre-test and Post-test differences of groups showed at Table 3. According to table important findings were about the flexibility and abdominal strength. T-test analysis proved that differences the pre-test and post-test flexibility performance of groups was significantly difference. When compared with the pilates group to control group, after six weeks of training periods, pilates group was statistically changed in flexibility performance (t:2.447 p:0.02). Analysis also proved that when compared with the pilates group to control group, after six weeks of training periods, pilates group was statistically changed in abdominal strength performance (t:2.447 p:0.02). Though self-esteem scores of pilates group were changed during the training period there wasn't any statistical finding when compared with the control group.

\section{DISCUSSION}

Pilates workouts became increasingly popular in community. This popularity makes curiosity the researcher to investigate this new exercise model. There were many studies which were investigated effects of different work load pilates training on different populations reported by Şimşek \& Katırc1 (37) and Cancela et al. 2014 (6). One of the investigated variables was the flexibility performance in this study. After the six weeks training period flexibility performance of the pilates group was statistically improved. There were many studies in literature reported that pilates exercises had positive effect on flexibility performance.
$(8,13,22,26,29,30,31)$. Primarily aim of Pilates exercises was the increasing the flexibility and strength of the body as known by the practitioners. It may due to having long duration stretching exercises of the abdominal and leg muscles, as a parallel with the previous studies flexibility performance was one of the improved variables as found in this study.

Pilates exercises also reported by researcher that regular pilates work outs had positive effects on muscle endurance $(28,29,32,33)$. Similar with the previous studies, in this study abdominal strength was statistically improved after six week pilates workouts. Because of the pilates workouts perform in a series of repetitive, high-low-impact muscular endurance exercises by using abdominal muscles, that exercises mainly effected to abdominal muscle endurance and flexibility.

One of the investigated variables in this study was the static balance performance. After six weeks of training periods there wasn't any statistical changing for balance performance. Literature has two answers for his situation. Some findings reported by previous researcher that pilates workouts has no effect on balance $(4,20)$ but some of findings showed that plates improved balance performance $(3,23,34)$. Those differences may cause of the different ages of the study groups and the different duration of the pilates periods. Especially 12 weeks of pilates work outs improved the balance performance as showed by Mokhtari et al. (23).

While biomotorical benefits of pilates exercises reported by the researcher, its' also effects on psychological parameters reported in literature. Participating in to regular physical activity has positive effect on self-esteem, self-confident, anxiety and depression reported by scientists $(5,36,40)$. Recent study found that as the similar the previous studies self-esteem scores of pilates group were statistically improved. We believe that this chancing may cause the positive improvement of physiological parameters.

In this study we did not find any statistical changing about Body Mass Index (BMI) of participants. Previous studies reported similar findings as we found. Researcher noticed that short term plates workouts (4-8 weeks) statistically has no effects on BMI $(1,14,17,19,32)$. On the other hand when periods of pilates exercises performed more than 8 weeks BMI scores effected positively as noticed by researcher $(9,38)$. 
Pilates exercise program for six weeks has a positive effect on flexibility, abdominal muscle strength and self-esteem. According to findings it is possible to say that six weeks of mat based pilates exercises were proper physical activity type for young girls.

\section{ACKNOWLEDGMENT}

We would like to thank to students of the Çanaklae Onsekiz Mart University for joined into the study voluntary. Also we would like thank to Physical Education and sport department to provide dance saloon for performing pilates exercises.

\section{REFERENCES}

1. Abramaviciûté $\mathrm{V}$, Zaicenkoviené $\mathrm{K}$, Sujeta $\mathrm{A}$, The Influence Of Pilates Exercise On Women's Anthrophometry Indices, Core Muscle Performance And Heart Rate Changes During The Session. Education. Physical Training Sport, 2013; 89: 5-11.

2. American College of Sports Medicine. Guidelines for exercise testing and prescription (6th ed.). Baltimore, MD: Lippincott Williams \& Wilkins, 2000.

3. Babayigit IB, Ozdemir RA, Evin R, Irez SG, Korkusuz F. Integrating Pilates exercise into an exercise program for 65+ year-old women to reduce falls. Journal of Sports Science and Medicine, 2011; 10; 105- 111.

4. Caldwell K, Harrison M, Adams M, Triplett NT, Effect of Pilates and taiji quan training on self-efficacy, sleepquality, mood, and physical performance of college students. Journal of Body work and Movement Therapies, 2009: 13; 155-163.

5. Calfas KJ, Taylor WC, Effects of Physical Activity on Psychological Variables in Adolescents. Pediatric Exercise Science, 1994; 6: 406-423.

6. Cancela JM, Oliveira IM, Fuentes GR. Effects of pilates method in physical fitness on older adults. A Systematic Review. Eur Rev Aging Phys Act, 2014; 11: 81-94.

7. Chang Y. Grace under pressure. Ten years ago, 5,000 people did the exercise routine called Pilates. The number now is 5 million in America alone. But what is it, exactly? Newsweek, 2000; 135: 72-73.

8. Chinnavan E, Gopaladhas S, Kaikondan P. Effectiveness of Pilates training in improving hamstring flexibility of football players. Bangladesh Journal of Medical Science, 2015; 14(3): 265-269.

9. Cristóbal RV, Alacid F, Ros FE, Muyor JM, Miñarro PÁL, The effects of 16-weeks pilates mat program on anthropometric variables and body composition in active adult women after a short detraining period. Nutr Hosp, 2015; 31(4): 1738-1747.

10. Deforche B, Lefevre J, De BI, Hills AP, Duquet W, Bouckaert J. Physical Wtness and physical activity in obese and nonobese Flemish youth. Obes Res, 2003; 11: 434-441.

11. DiNucci J, McCune D, Shows D. Reliability of a modification of the health - related physical fitness test for use with physical education majors. Research Quarterly for Exercise and Sport, 1990: 61: 20-25.
12. Emerya KDS, S. J. M., Ann Côtéa, Julie N., The effects of a Pilates training program on arm-trunk posture and movement. Clinical Biomechanics, 2010: 25: 124-130.

13. English T, Howe K. the effect of pilates exercise on trunk and postural stability and throwing velocity in college Q3 baseball pitchers: Single Subject Design. N Am J Sports Phys Ther, 2007; 2: 8-19.

14. Erkal A, Arslanoğlu C, Reza B, Şenel Ö. Effects of eight weeks pilates exercises on body composition of middle aged sedentary women. Ovidius University Annals, Series Physical Education \& Sport/Science, Movement \& Health, 2011; 11(1): 86-89.

15. Finch C, Cassell E. The public health impact of injury during sport and active recreation. Journal of Science and Medicine in Sport, 2006; 9: 490-497.

16. Finch C, Owen N, Price R. Current injury or disability as a barrier to being more physically active. Medicine and Science in Sports and Exercise, 2001; 33: 778-782.

17. Fourie M, Gildenhuys GM, Shaw I, Shaw BS, Toriola AL, Goon DT. Effects of a mat pilâtes programme on body composition in elderly women. The West Indian Medical Journal, 2013; 62(6): 524-528.

18. Herrington, L., Davies, R., The influence of Pilates training on the ability to contract the transversus abdominus muscle in asymptomatic individuals. Journal of Bodywork and Movement Therapies, 2005; 9(1): 52-57.

19. Jago R, Jonker ML, Missaghian M, Baranowski T, Effect of 4 weeks of Pilates on the body composition of young girls. Preventive Medicine, 2006; 42 : 177 - 180

20. Kloubec JA. Pilates for improvement of muscle endurance, flexibility, balance, and posture. Journal of Strength and Conditioning Research, 2010; 24(3): 661-667.

21. Kuo YL, Tully EA, Galea MP. Sagittal spinal posture after Pilates-based exercise in healthy older adults. Spine, 2009; 34(10): 1046-1051.

22. Mıkalačkı M, Emeše M, Čokorılo N, Korovljev D, Ruız Montero PJ. Analysis of the effects of a pilates program on the flexibility of women. Facta Universitatis : Physical Education and Sport, 2012: 10(4, Special Issue): $305-309$.

23. Mokhtari M, Nezakatalhossaini M, Esfarjani F, The effect of 12-week pilates exercises on depression and balance associated with falling in the elderly. Procedia - Social and Behavioral Sciences, 2013; 70: $1714-1723$.

24. Muscolino J, Cipriani S. Pilâtes and the "powerhouse"- I. Journal of Bodywork and Movement Therapies, 2003; 8: 15-24.

25. Gorji NE, Habibian M, Farzanegi P. 8 weeks pilates training effects on fetuin-a levels and anthropometric indicators in sedentary overweight women. International Medical Journal, 2014; 21(6): $548-551$.

26. Otto R, Mary Y, Kathleen M, Jaclyn M, Anthony V, Andrea L, Michael L, John W. The effect of 12 weeks of pilates vs. resistance training on trained females. Med Sci Sports Exerc, 2004; 36(5): 356-357.

27. Owsley A. An introduction to clinical Pilates. Athlet Ther Today, 2005; 10(4): 19-25. 
28. Rogers K, Gibson AL, Eight-Week Traditional Mat Pilates Training-Program Effects on Adult Fitness Characteristics, Research Quarterly for Exercise and Sport, 2009; 80(3): 569-574.

29. Rogers KV, Gibson AL. Effects of an 8-week mat pilates training program on body composition, flexibility, and muscular endurance. Med Sci Sports Exerc, 2006; 38(5): 279280.

30. Schroeder JM., Crussemeyer JA., Newton SJ. Flexibility and Heart Rate Response to an Acute Pilates Reformer Session. Medicine Science in Sports Exercise, 2002: 34(5): 258-263.

31. Segal NA, Hein J, Basford JR. The effects of pilates training on flexibility and body composition: an observational study. Arch Phys Med Rehabil, 2004: 85(12): 1977-1981.

32. Sekendiz B, Altun Ö, Korkusuz F, Akın S. Effects of pilates exercise on trunk strength, endurance and flexibility in sedentary adult females. Journal of Bodywork and Movement Therapies, 2007; 11: 318-326.

33. Sewright K, Martens DN, Axtell RS, Rinehardt KF, Effects of 6 weeks of pilates mat training on tennis serve velocity, muscular endurance, and their relationship in collegiate tennis players. Med Sci Sports Exerc, 2004; 36(5): 167-171.

34. Smith K, Smith E. Integrating Pilates-based core strengthening into older adult fitness programs implications for practice. Topics in Geriatric Rehabilitation, 2005; 21(1):17-67.
35. Stanko E. The role of modified Pilâtes in women's health physiotherapy. Journal of the Association of Chartered Physiotherapists in Women's Health, 2002; 90: 21-32.

36. Sung PM, Soon KM. Effects of yoga exercise program on response of stress, physical fitness and self-esteem in the middle-aged women. Korean Journal of Adult Nursing, 2014; 26(1): 22-33.

37. Şimşek D, Katırcı H. The Influence of pilates exercises on postural stability and sports performance: a systematic review of the literature. Nigde University Journal of Physical Education and Sport Sciences, 2011: 5(2): 58-70.

38. Tsai YW., Liou TH., Kao YH., Wang KM., Huang YC. Effect of a 12-week pilates course on body composition and cardiopulmonary fitness of adults living in an urban community. South African Journal for Research in Sport, Physical Education and Recreation, 2013: 35(2): 183-195.

39. Tufan, B., Turan, N. Coopersmith Benlik Saygısı Ölçeği Üzerinde Geçerlik, Güvenirlik Çalışması. 23. Ulusal Psikiyatri Kongresi Bildirileri, İstanbul, 1987.

40. Yiğiter $\mathrm{K}, \mathrm{A}$ comparative study on American and Turkish students' self-esteem in terms of sport participation: A study on psychological health. Educational Research and Reviews, 2014: 531-534. 